\title{
PENGOLAHAN SAGU MENJADI SINOLEDENGANVARIAN RASA DI MASYARAKAT TANA LUWU: SEBAGAI UPAYA PENAMBAHAN EKONOMI SELAMA PANDEMI COVID-19
}

\author{
Indra Kusdarianto'), Harmita Sari ${ }^{11}$ \\ 1)Program Studi Manajemen, Fakultas Ekonomi dan Bisnis, Universitas Muhammadiyah Palopo, Palopo, \\ Sulawesi Selatan, Indonesia \\ Corresponding author : Harmita Sari \\ E-mail : harmitasari93@gmail.com
}

Diterima 28 April 2021, Direvisi 01 Agustus 2021, Disetujui 01 Agustus 2021

\begin{abstract}
ABSTRAK
Tepung sagu adalah tepung yang berasal dari teras batang pohon sagu. Tepung sagu biasa digunakan sebagai salah satu bahan baku kue atau penganan lainnya. Pembuatan kue, sagu biasanya digunakan sebagai bahan pengental karena tepung ini bersifat lengket. Tepung sagu kaya dengan karbohidrat (pati) namun sangat miskin gizi lainnya. Ini terjadi akibat kandungan tinggi pati di dalam teras batang maupun proses pemanenannya. Sagu merupakan makanan pokok bagi masyarakat Indonesia seperti Maluku, Papua yang tinggal di pesisir dan banyak dijumpai di daerah Sulawesi Selatan khususnya di kota Palopo, dan Kabupaten Luwu yang dikenal dengan nama Sagu. Sagu dimakan dalam bentuk papeda, semacam bubur, atau dalam bentuk-bentuk yang lain. Sagu sendiri dijual sebagai tepung curah maupun yang dipadatkan dan dikemas dengan daun pisang. Selain itu, saat ini sagu juga diolah menjadi kue berbagai rasa seperti sinole. Jika usaha ini ditekuni dengan baik, maka akan memberikan kontribusi pendapatan bagi masyarakat Luwu dimasa pandemi Covid-19. Untuk itu, dalam memberikan kontribusi kepada masyarakat, semoga dengan adanya edukasi pengolahan sagu ini, mampu memberikan pemahaman kepada masyarakat bahwa sagu bisa diolah menjadi berbagai varian rasa sehingga hal ini menjadi referensi bagi masyarakat agar dapat memanfaatkan Sumber Daya Alam yang ada di daerahnya yaitu sagu menjadi nilai ekonomi.
\end{abstract}

Kata Kunci: tepung sagu; sinole; penambahan ekonomi.

\begin{abstract}
Sago flour is flour that comes from the terrace of the sago palm tree. Sago flour is commonly used as a raw material for cakes or other snacks. In making cakes, sago is usually used as a thickening agent because this flour is sticky. Sago flour is rich in carbohydrates (starch) but very poor in other nutrients. This occurs due to the high starch content in the stem terraces and the harvesting process. Sago is a staple food for Indonesian people such as Maluku, Papua who live on the coast and can be found in South Sulawesi, especially in the city of Palopo, and Luwu Regency which is known as Sago. Sago is eaten in the form of papeda, a kind of pulp, or in other forms. Sago itself is sold as bulk flour or compressed and packed with banana leaves. In addition, at this time sago is also processed into cakes of various flavors such as sinole. If this business is weel pursued, it will contribute to income for the people of Luwu during the Covid-19 pandemic. For this reason, in contributing to the community, hopefully with this education on sago processing, it will be able to provide an understanding to the community that sago can be processed into various flavors so that this becomes a reference for the community so that they can take advantage of the existing natural resources in their area, namely sago. economic value.
\end{abstract}

Keywords: sago flour; sinole; economic income.

\section{PENDAHULUAN}

Masyarakat luwu dikenal dengan sumber daya alamya yaitu sagu, namun dalam mengelolah sagu menjadi hal yang menarik masyarakat masih perlu diberikan bagaimana mengolah sagu menjadi sesuatu yang menarik dan menghasilkan nilai ekonomi apalagi dimasa pandemi ini.

Sagu memiliki potensi yang paling besar untuk digunakan sebagai alternatif sumber 
karbohidrat. Tingkat produktifitas sagu di Provinsi Gorontalo mencapai $333 \mathrm{~kg} / \mathrm{Ha}$, jika produktifitas sagu dalam menghasilkan pati sebesar $15-25 \mathrm{t} / \mathrm{ha} / \mathrm{thn}$, lebih tinggi dibanding kandungan pati pada beras, jagung dan gandum yang berturut-turut sebesar $6 \mathrm{t} / \mathrm{ha}, 5,5 \mathrm{t} / \mathrm{ha}$ dan 2,5 t/ha (PKPP, 2012). Sehingga, dapat dikatakan bahwa tepung jenis sagu cukup prospektif di Provinsi Gorontalo untuk dikembangkan karena memiliki ketersediaan bahan baku yang mencukupi. Syarat-syarat agronominya juga lebih sederhana dibandingkan tanaman lainnya dan pemanenannya tidak tergantung musim (Koswara, 2006).

Gorontalo sebagai salah satu daerah di Kawasan Timur Indonesia memiliki banyak variasi dalam pemanfaatan sumber daya pangan lokal, salah satunya adalah sagu (Metroxylon sp.). Sagu banyak ditemukan di daerah Kabupaten Bone Bolango, Kabupaten Boalemo dan Kabupaten Pohuwato. Walaupun demikian, popularitas sagu sebagai penghasil karbohidrat di Provinsi ini masih jauh di bawah beras dan jagung. Sagu dapat dimanfaatkan sebagai bahan pangan setelah berbentuk tepung dan digunakan pada berbagai jenis olahan makanan antara lain papeda maupun kapurung dimana fungsi kedua makanan tersebut hanyalah sebagai makanan selingan saja (PKPP, 2012).

Tepung sagu adalah pati yang diperoleh dari pengolahan empelur pohon sagu (Metroxylon sp.). Produk-produk makanan sagu tradisional dikenal dengan nama papeda, sagu lempeng, sagu tutupala, sagu uha, sinoli, bagea, dan sebagainya. Sagu juga digunakan untuk bahan pangan yang lebih komersial seperti roti, biskuit, mie, sohun, kerupuk, hunkue, bihun, dan sebagainya (Auliah, 2012).

Sama halnya dengan pernyataan PKPP (2012) bahwa teknologi pengolahan yang berkembang saat ini memungkinkan adanya diversifikasi produk pangan yang berbasis pada tepung sagu, yakni bisa dikembangkan mulai dari pembuatan produk tepung sagu komposit, mie, cake, cookies, dan produk-produk lain dan kami buat dan di paparkan di kota Belopa pembuatan Sinole varian rasa. Pengolahan Sinole di kota belopa ini kami belum mempasarkannya karna produksi yang kami buat belum bisa untuk dipasarkan langsung kami hanya bisa memasarkannya dengan online karna kelemahan dari tepung sagu ini kalau sudah di olah menjadi Sinole jika sudah di ingin rasanya sudah tidak sedap lagi dan digigitpun keras. Hasbi (2020) menyatakan bahwa atribut yang palingdipertimbangkan dalam melakukan pembelian olahan sagu dimulai dari faktor harga, kedua faktor merek,ketigafakt or rasa, dan kemudahan memperoleh. Adapun tujuan dari kegiatan ini, sebagai konribusi kepada masyarakat bagaimana mengolah sagu menjadi sinole dengan berbagai varian rasa sehingga menarik dan mampu menghasilkan nilai ekonomi bagi masyarakat Luwu apa lagi di masa pandemi saat ini.

\section{METODE}

Kegiatan pengabdian ini dilaksanakan di jalan jendral Sudirman, Tampumia Radda,Kota Belopa, Kecamatan Belopa, Kabupaten Luwu. Peserta yang mengikuti kegiatan ini berjumlah 5 orang yang merupakan perwakilan dari masyarakat muda-mudi kota belopa. Metode yang dilakukan dalam kegiatan pengabdian ini hanya memakan waktu beberapa menit saja.

Tahap pertama kegiatan adalah tahap persiapan, apa saja yang disiapkan dalam mengolah sagu menjadi sinole dengan bergbagai varian rasa. Selain itu juga berupa penyuluhan tentang Tepung sagu kaya dengan karbohidrat(pati) namun sangat miskin gizi lainnya. Ini terjadi akibat kandungan tinggi pati di dalam teras batang maupun proses pemanenannya.

Tahap kedua yaitu tahap kegiatan yakni memberikan edukasi dan sosialisasi bagaimana pengolahan tepung Sagu untuk di olah menjadi Sinole rasa dan kami mengolah Sinole dengan 2 varian rasa yaitu gula merah dan Coklat dan 2 model Sinole ada yang bentuk dadar dan biasa.

Bahan yang digunakan meliputi tepung sagu, garam, gula merah, kelapa, coklat. Sedangkan alat yang digunakan antara lain kompor gas, wajan, Spatula stainless, wajan.

Pada akhir pelatihan dilakukan evaluasi dan monitoring dengan cara wawancara kepada para masyarakat yang ikut sertamengenai hasil pembuatan tepung sagu yang dibuat menjadi Sinole berbagai varian rasa.

\section{HASIL DAN PEMBAHASAN}

Berwirausaha di tengah pandemi covid19 dengan memanfaatkan berbagai potensi atau sumber daya alam contohnya sagu yang ada di Luwu Belopa (Sari, 2021). Merupakan solusi untuk mengatasi ekonomi yang terjadi selama pandemi covid-19. Berikut relasi kegiatan yang dilakukan tim pengabdian.

Kegiatan ini dihadiri oleh 5 orang peserta yang berasal darikota Belopa, seperti terlihat pada Gambar 1 dan melaksanakannya 
bersama kelompok itu secara online melalui google meet.

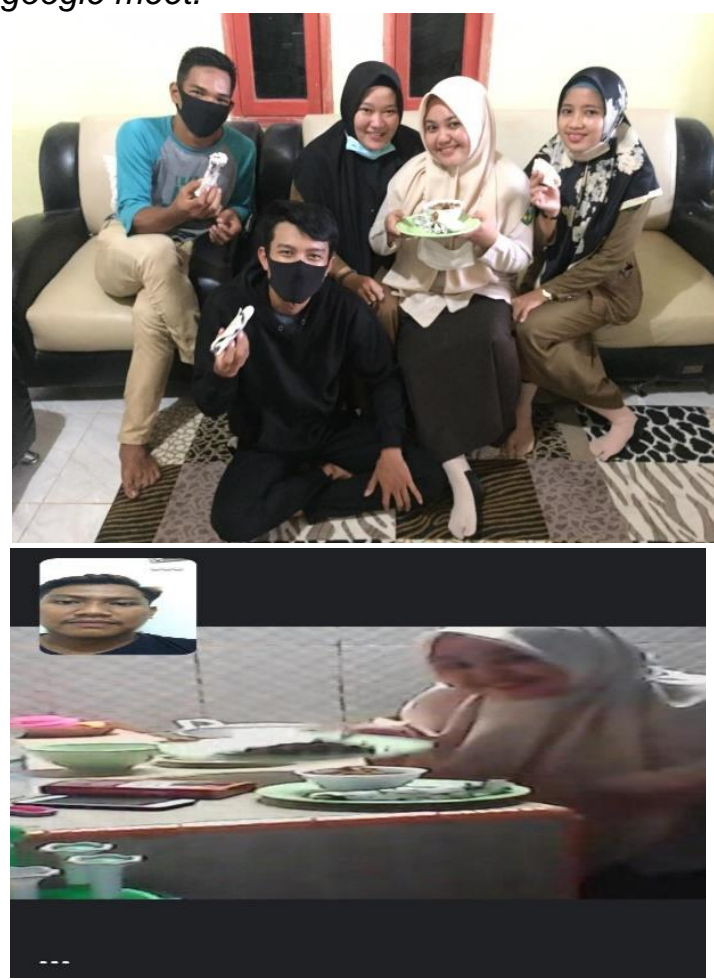

Gambar 1. Peserta penyuluhan dan kelompok melalui google Meet (Sumber: Evi Mayasari)

\section{Kegiatan Pelatihan}

Kegiatan

dilakukan untuk mempraktikan secara langsung teori yang sudah disampaikan pada tahap penyuluhan. Suasana kegiatan pengolahan tepung Sagu menjadi Sinole berbagai rasa dapat dilihat pada Gambar 2.

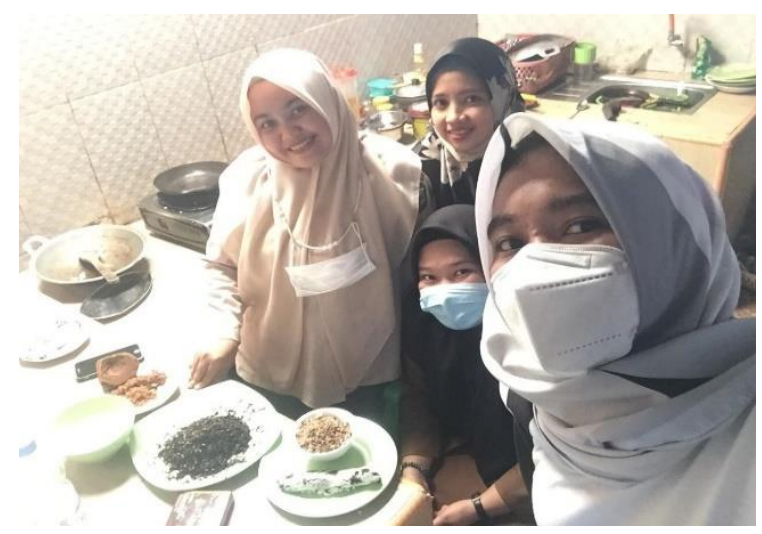

Gambar 2. Suasana kegiatan proses pembuatan sinole (Sumber: Evi Mayasari)
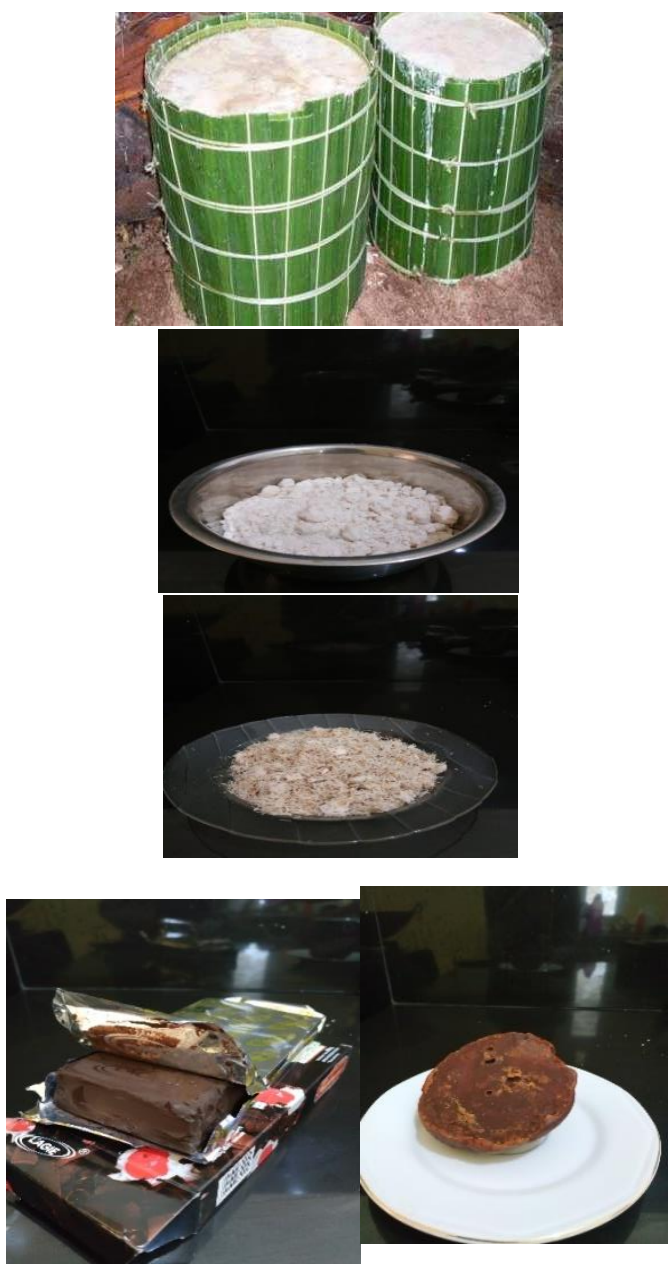

Gambar 3.Bahan wajib Sinole (Sumber: Harmita Sari)

2) Sagu dan kelapa tambahkan garam setengah sendok teh disatukan di wadah untuk dicampurkan menjadi satu
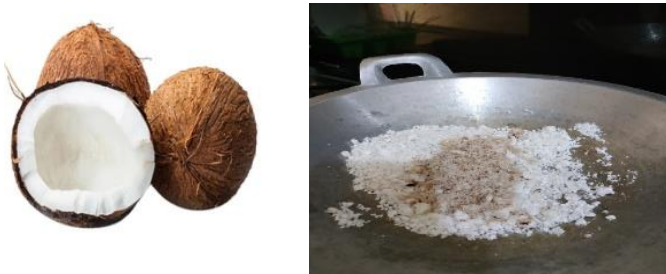

Gambar 4. Campuran sagu dan bahan lainnya (Sumber: Harmita Sari)

3) Jika ingin menggunakan sinole rasa coklat dan rasa lainnya tidak usah menggunakan garam cukup menggunakan bahan rasa varian coklat, greentea untuk dibagian dalam/tengah sebagai isian sinole dadar.

Tahapan yang dilakukan, yaitu:

1) Siapkan semua bahan terlebih dahulu: 


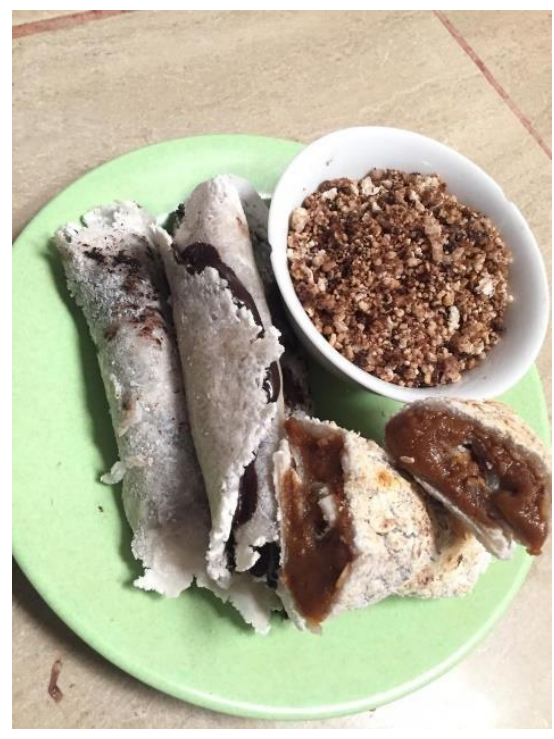

Gambar 5. Hasil dari sinole rasa varian (Sumber: Harmita Sari)

Sinole memiliki rasa yang unik, cita rasanya yang hambar berpadu dengan gurihnya parutan kelapa dapat terasa di lidah dengan cukup jelas. Tekstur lembutnya tepung sagu pun masih dapat terasa sekalipun makanan ini sudah dimasak hingga matang. Tekstur ini memang sengaja dipertahankan agar kenikmatan makanan ini pun tetap terjaga. Sinole cukup fleksibel untuk dinikmati, dapat menjadi pilihan makanan pokok seperti beras, atau dapat juga dinikmati sekedar sebagai teman minum teh saat pagi dan sore hari.

Berdasarkan hasil wawancara kepada para peserta diketahui bahwa pada umumnya peserta cukup puas dengan kegiatan yang diikuti dan pelatihan pengolahan Sagu menjadi Sinole, karena kegiatan ini menambah pengetahuan dan keterampilan peserta tentang manfaat dan pengolahan Sagu.

Pada masa pandemi virus corona atau Corona Virus Disease 2019 (Covid-19), pemerintah menghimbau kepada masyarakat untuk bekerja dari rumah atau Work From Home (WFH), larangan berkumpul atau berkerumun, dan menjaga jarak antara satu individu dengan individu lainya. Seiring adanya aturan tersebut maka dibeberapa wilayah terdampak, terjadi perlambatan kegiatan usaha yang merata di seluruh Indonesia. Maka salah satu peluang bisnis yang perlu untuk dikembangkan adalah pengolaan makanan sinole dengan rasa varian. Sinole adalah makanan sederhana, namun apabila diolalah dengan tangan-tangan yang trampil maka makanan ini menjadi makanan favorit bagi semua kalangan.

\section{SIMPULAN DAN SARAN}

Pengolahan Sagu menjadi berbagai produk olahan pangan seperti Sinole merupakan salah satu alternatif untuk meningkatkan nilai tambah dan penganekaragaman pangan pokok yang selama ini masih terbatas. Pelaksanaan kegiatan ini berjalan lancar dan sukses. Peserta pelatihan mendapatkan ilmu pengetahuan dan keterampilan baru dalam memanfaatkan dan mengolah Sagu menjadi berbagai produk olahan lokal, yang selanjutnya dapat dikembangkan menjadi salah satu sumber ekonomi bagi warga masyarakat Luwu di kecamatan Belopa. Jika usaha ini kedepannya ditekuni dengan baik, maka akan memberikan kontribusi pendapatan bagi masyarakat Luwu dimasa pandemi Covid-19.

\section{Saran}

Adapun Saran dari Kegiatan ini adalah kami belum sepenuhnya bisa mengarahkan dan menjelaskan banyak hal tentang masyarakat dengan olahan sagu ini menjadi Sinole dan kami masih perlu melakukan pelatihan khusus mengenai proses pemasaran, desain, dan pengemasan produk olahan pangan agar produk yang dihasilkan dapat dipasarkan menarik minat pembeli.

\section{UCAPAN TERIMA KASIH}

Terima kasih kami sampaikan kepada Masyarakat Luwu yang ikut serta dalam kegiatan pengolahan tepung sagu menjadi Sinole dan bisa menyempatkan waktu secara langsung ikut serta dalam hal proses pembuatan dan penyicipan produk olahan sagu.

\section{DAFTAR RUJUKAN}

Anton Djuwardi. (2001). Cassava Solusi Pemberagaman Kemandirian Pangan. Grasindo. Jakarta

Flach, M. (1996). Sago Palm. International Plant Genetic Resourches Institute (IPGRI) Promoting The Concervation and Use Underulitized and Neglected Crops, 13. IPGRI, Italy and IPK Germany.

Hayati, N., R. Purwanti dan A. Kadir W. Preferensi Masyarakat Terhadap Makanan Berbahan Baku Sagu (Rottb) Sebagai Alternatif Sumber Karbohidrat Di Kabupaten Luwu Dan Luwu Utara Sulawesi Selatan. JURNAL Penelitian Sosial dan Ekonomi Kehutanan, 11 (1): $82-90$

Hasbi, A. R dan Sari, H. (2020). Atribut Produk yang Dipertimbangkan dalam 
Pembelian Olahan Sagu di Kota Palopo. Jurnal Ilmu Pangan dan Hasil Pertanian, 4 (1): 7-14.

Ishizaki, A. (1997). Concluding Remarks for the Sixth International Sago Symposium at Riau, Indonesia. Sago Communication 8 (pp. 22-25). Japan: Tsukuba Sago Fund.

Kanro, M. Z., A. Rouw, A. Widjono, Syamsuddin, Amisnaipa, dan Atekan. (2003). Tanaman Sagu dan Pemanfaatannya di Propinsi Papua. Jurnal Litbang Pertanian, 22(3): 116-124

Karim, A. A., A. T. Pei-Lang, D.M.A. Manan, and I.S.M. Zaidul. (2008). Starch from the Sago (Metroxylon sagu) Palm TreeProperties, Prospects, and Challenges as a New Industrial Source for Food and Other Uses. Comprehensive Reviews in Food Science and Food Safety Vol.7

Pei-Lang, A.T., A.M.D. Mohamed and A.A. Karim. (2005). Sago Starch and Composition of Associated Components in Palms of Different Growth Stages. Carbohydrate Polymers 63 (2006) 283286

Radley, J.A. (1976). The Minor Starches of Commerce: The Manufacture of Rice, Arrowroot and Sago Starch, Starch production technology, Applied Science Publishers Ltd, London (1976), pp. 229246.

Sari, Harmita, dkk. (2021). Integritas Pendidikan Menuai Wirausaha Di Era Pandemi Desa

Buntu Karya Kecamatan Luwu Kabupaten Ponrang Selatan Provinsi Sulawesi Selatan. Jurnal SELAPARANG. Jurnal Pengabdian Masyarakat Berkemajuan, 4 (2): 34-40. 